of London began in 1828 , and when University College was incorporated in 1836 , Oxford and Cambridge had not dreamt of throwing open their doors to dissenters. Today the whole world so absolutely recognises the propriety of the step which University College then took, that it is difficult to give it enough credit for a courage which was then without precedent in England. Only the other day its invitation has been widened still farther. Cuncti adsint is to be understood as including Cuncte adsint, and women as well as men will henceforth have unrestricted access to the classes in the faculties of arts, law, and science. Women are at least as much influenced in character by the kind of education which is given them as men are, and the action of University College guarantees that women-in London, at least-will have at their disposal the best education which England can offer.

The Chancellor of the University of London reminded us that the new demands of teachers of science have compelled institutions like University College to extend their buildings and to provide laboratory facilities in addition to the class-rooms and lectures of old days. University College is not alone in recognising this vital fact. King's College has thorougbly developed its practical teaching; the Scotch Universities have latterly been vry much alive on the subject; Owens College, as becomes a new institution claiming to take rank with the most advanced teaching bodies of the day, has given exceptional prominence to laboratory work. But University College has not been unconscious of the movement, and she purposes, if possible, to outstrip her rivals.

The last movement, in which Lord Granville reminds us that her action has counted for a great deal, is that to extend the English definition of a university. She considers herself entitled to that appellation. "Now the term ' University,' " says Lord Granville, "has been differently understood by different persons and by different nations, and I think that the exact construction of it is rery likely to be still more minutely debated in consequence of the able efforts of one of the most distinguished sturlents of your college, now the most successful president of Owens College, whom we sec among us, who has raised the question whether the number of universities ought not to be increased. In France 'university' means an aggregrate of all the schools and colleges of the kingdom. In Germany their famous universities are really professorial schools. Our two elder universities are really academical institutions-an aggregate of colleges. You know that the London University is not a teaching body at all, and that it is only an examining body, depending upon other sources, of which this college is the most prolific in giving us candidates for our cxaminations." The institution of University College has done much, the movement of Owens College has done more, to widen our ideas of what a University might do. There is no reason why we should be confined to the cxisting type of "academical institutions-an aggregate of colleges," supplemented by an examining body depending on other sources. We do not aim at French centralisation, but there is no reason why one or two universities on the German or the Scotch model should not be added to the very limited list of our English
Universities. An amalgamation of University College and King's College into a teaching University of London would be a natural consequence of such a movement.

\section{WINDMILLS AND WATERFALLS}

O $U R$ readers may remember the consternation caused some years ago by the publication of Prof. Jevons's work on our coal supplies, and the alarmed inference drawn from his calculations that the days of Britain's supremacy and prosperity were numbered. Certainly, if our prosperity is entirely dependent on our coal supplies, there can be no doubt that ere very long the beginning of the end will have arrived. Abundant as our coal supplies are their consumption at the rate of about 150 million tons annually cannot go on for ever; and while we may have the ships and the money too, it would be a serious thing for England if she had to look abroad for her greatest source of physical power. It is certainly at present difficult to see how the work of the world could be carried on if the supply of coal were completely exhausted; still if man were compelled to find a substitute or relapse into savagery or even perish altogether, we think the chances are he would be able in some way, without detriment to his progress, to adapt himself to his new circumstances. These ideas have been suggested by an interesting lecture, just published, recently delivered at Glasgow by Dr. C. W. Siemens, "On the Utilisation of Heat and other Natural Forces."

"The supremacy," he justly says, "which man enjoys over the animate and inanimate creation, and for which Divine Authority may be quoted, cannot be said to be the result of his superior muscular development, for amongst the members of the animal kingdom there are many which are his superiors in strength, agility, swiftness, and in natural aptitude to provide themselves against the vicissitudes of cold and hunger. The compensating advantage in our favour is the intelligence with which we are enabled to call forces of nature not our own into requisition to do our behests. It would not be too much to say that the power of man consists really in his ability to direct the forces of nature, and that the degree of civilisation to which he has attained is commensurate with his command of those forces."

Could any more forcible argument be urged in favour of the national advantages of scientific research, or of the yearly increasing importance of scientific knowledge in the every-day life of humanity?

Fortunately Dr. Siemens, in his lecture, gives us a pretty wide glimpse of hope that we need not despair because of the prospective exhaustion of the existing means of producing utilisable heat. Other methods, he suggests, might be found of bringing into action this greatest source of mechanical power, and that even now one of these methods might be so used that the exhaustion of our coal might be postponed for a considerably longer period than has been calculated. Dr. Siemens traces the progress of our knowledge of the real nature of heat and of the methods of ascertaining its mechanical equivalent. He shows how gradually we have learned to produce a greater and greater amount of mechanical effect from the 
consumption of a certain quantity of heat in the steamengine, the blast-furnace, and other methods of utilising this source of power as derived from coal, and points out how, by means of electricity, this agent may be made to do a greater amount of work for us than ever. The wonderful results obtained from the Siemens' dynamo-electric machine are well known, and Dr. Siemens gives an example of the saving of power that might be effected by its use :-

"Let us suppose that at some central station Ioo horsepower of steam or water power was employed to give motion to several dynamo-electric machines of the dimensions found most convenient in practice, and that by means of metallic conductors of suitable dimensions the electric current produced at the central station was conducted to a number of halls or factories requiring to be lighted, or to utilise mechanical power. If illumination were the only object in view, the total amount of light that could be thus produced would be equal to 125,000 candle-power. This would be equivalent to 6,250 Argand burners, each of 20 candle-puwer, at a consumption per burner of 6 cubic feet of gas per hour, or a total consumption of 37,500 cubic feet of gas to produce the same effect of light. This would require $3 \frac{3}{4}$ tons of coal, and the electric light about as many hundredweights."

Now if the power to drive these machines could be obtained apart from coal the addition to our mechanical resources would be immense. While Dr. Siemens shows that the tides are a source of power that might be utilised directly or indirectly, he at the same time shows that the results would not be at all commensurate to the work expended. But the old sources of power, which have gradually given way before the universal introduction of steam-wind and falling water-might again be called into play, and with infinitely greater effect than ever. It is cvident that within certain limits the rotatory motion required for the working of the dynamo-electric machine might be effected by means of the old-fashioned windmill, and to a much greater extent by means of falling water. Our readers may remember that Dr. Siemens, some months ago, in an address which he then gave, referred to the immense quantity of power which flowed ready made over the Falls of Niagara. In his Glasgow address he again referred to the subject, in order to show how this gigantic source of power might be utilised to produce action at a distance. "When," he says, "little more than a twelvemonth ago I visited the great Falls of Niagara, I was particularly struck with the extraordinary amount of force which is lost, as far as the useful purposes of man are concerned. 100,000,000 of tons of water fall there every hour from a vertical height of 150 feet, which represent an aggregate of $16,800,000$ horsepower, producing as their effect no other result than to raise the temperature of the water at the foot of the fall

$$
\frac{150}{772}=\frac{1^{\circ}}{5^{\circ}} \text { Falir. }
$$

In order to reproduce the power of $16,800,000$ horses, or, in other words, to pump back the water from below to above the fall, would require an annual expenditure of not less than 266,000 , ooo of tons of coal, calculated at an average consumption of 4 lbs. of coal per horse-power per hour: which amount is equivalent to the total coal consumption of the world. In stating these facts in my inaugural address on assuming the presidency of the Iron and Steel Institute, I ventured to express the opinion that in order to utilise natural forces of this description at distant towns and centres of industry the electric conductor might be resorted to. This view was at that time unsupported by experimental data such as I have been able since then to collect." Dr. Siemens then shows what has been done in conveying the electric light to a distance; and he points out that, "if mechanical force is required to be distributed, the arrangements are in every respect similar to those for the distribution of electric light ; and it has been proved experimentally that the amount of power recovered at the distant station is nearly equal to half the power employed at the central station." Even as regards the consumption of coal, were that article used, Dr. Siemens shows that the magneto-electric machine is cheaper than the gas or steam-engine. But he rightly says :- "It would not be necessary to seek on the other side of the Atlantic for an application of this mode of transmitting the natural force of falling water, as there is perhaps no country where this force abounds to a greater extent than on the west coast of Scotland, with its elevated lands and heavy rainfalls. You have already conducted the water of one of your high-level lochs to Glasgow by means of a gigantic tube ; and how much easier would it be to pass the water in its descent from elevated lands through turbines, and to transmit the vast amount of force that might thus be collected, by means of stout metallic conductors, to towns and villages for the supply of light and mechanical power!"

Dr. Siemens points out other directions in which the natural forces of the universe might be used for the pur. poses of man, without resorting, to such an extent as we do at present, to our coal supplies. While windmills are directly rather an uncertain source of power, still, he shows that a number of windmills, such as may be constantly seen working in Holland for the drainage of the land, might, for instance, be employed to raise water, by pumping, to an elevated lake or reservoir, whence the power could be drawn off by means of hydraulic motors when required, and might be conducted electrically to centres of habitation.

We ought to be grateful to Dr. Siemens for taking so much pains to lighten up the gloomy prospects which some pessimists have been presenting to us for some years past; and to those who may be cynical enough to reply that a return to the windmill and the water-wheel is simply a sign of the prophesied retrogression, we may fitly reply, in Dr. Siemens' own words :-

"It would be wrorig to suppose that a resumption of the use of natural forces would throw us back to the time of the windmill and the primitive water-wheel which used to give motion to isolated establishments. We shall have learned to store, to transport, and to utilise these forces in a manner adapted to our superior requirements; and who knows whether the time may not come when our descendants in the third or fourtb generation will look back upon the indiscrimate users of coal with something like the same feeling that we look upon the users of flint and bronze implements. Indecd, without waiting for the extinction of our conl-fields, it 
appears: to me not improbable that natural forces will be resorted to simply on account of their comparative cheapness' and convenience of application."

\section{WEST YORKSHIRE}

West Yorkshine: an Account of its Geology, Physical Geograpky, Climatology, and Botany. Part I.-Geology. By J. W. Davis, F.G.S., F.L.S. Part II.-Physical Geography and Botanical Topography. By J: W.- Davis and F. Arnold Lees, F.L.S. With Maps and.Plates. (L. Reeve and Co., I 878.)

THE merit of a work on local geology or natural history may be of two distinct kinds. The author may be an original investigator of a little-known area, and his book a positive addition to our knowledge; or the wolume may be a tapestry, into which the'scattered threads of information are worked by one who has the mastery of them all, and who presents us with the picture they have formed in his mind. It is to excellence of this latter kind the authors of "West Yorkshire" aspirc. They have gathercd from the contributions of all local observers, and have so assimilated the material with their own knowledge, as to render the substance of their book a useful outline of the geology and botany of the district they have chosen to illustrate. An area included within the rcgion of Prof. Phillips's classical work on the mountain limestone districts of Yorkshire, and upon whose coal-bearing: and associated strata so much good work has been done by the Government Survey, does not leave nuch room for novelty in its geology, though the botany, respecially:as :treated in this book, is in rather a different case: The great merit of the work would therefore consist in the lucid and comprehensive manner in swhich it presents the scattered information to us as a wholc. This, however, it scarcely possesses in as great a degree as most of the books of its class.

Fxamined in detail there are some points which call for remark. The introductory chapter is mostly occupied with a description of the boundary line of the riding $\rightarrow$ a most unintcresting subject-but it is enlivened by the accounts of the Pennine: and Craven faults. The drawing of the Latter, however, on the maps does not coincide with the description, and the former is scarcely indicated. This map - a inost excellent one and derived from the best sources -unfortunately contains one or two other errors, viz., the Ingleton coal-field is wrongly coloured, and the words "upper Silurian". and "lower Silurian" are mismatched in the "references." In the next chapter the small Silurian area is well.though shortly described, and we are then very admirably shown that the red conglomerates at the base of the mountain limestone in some places are the shore clcposits of the early part of the latter epoch. The fricce de résistance, however, of this portion of the book is naturally the chapter which treats on the Carboniferous period, in which also are to be found the chief novelties due to the author. The lie and position of the great masses which form the backbone of the country are admirably given, and all the lately acquired information is incorporated. The lists of fossils, however, from the lower rocks, do not seem to have undergone much critical revision, and remarkably few additions scem to be recorded during the last thirty years. It is interesting to notice that, with respect to the lower coal measures, the author states his conviction that "the tendency of all the evidence in this part of the country is to show that the Gannister series and the Millstonc grits form one natural division of the Carboniferous systcm," though he does not go so far as Prof. Huil in classifying them together. A valuable feature here is a set of comparative sections in different districts in which the locally-named coal beds are correlated, and which gives a very good idea of their changes. Some of the most interesting features of the Yorkshire coals, however, such as the convergence of many seams into the Beeston coal and the peculiar character of the Better bed coal, though mentioned, are scarcely made enough of, but the fossils associated with the latter have been very well worked at. The proof of the unconformity of the permian limestones and the true age of the picturesque Plimpton rocks, once associated with them, is admirably given, and then this part: of the work concludes with an account of the superficial deposits, glacial striz, and the Victoria Cave.

The second part, which, according to the preface, is only the introductory chapter to the complete flora of the Riding, to be produced in another volume, is more interestingly written. The area under consideration is divided into ten districts indicated on a map, and coinciding with the drainage areas. In each of these the relation of the flora to the general physical characters is pointed out, and lists of the most interesting plants found in selected and naturally separate localities are given, accompanied by remarks on the surrounding country. In eacb we are taken to the head sources of the river which runs through the district, and so pleasantly are wc led along its banks that we seem to realise the several beauties of the neighbourhood while we learn their cause, and to collect all the interesting plants whose habitats are so graphically described. Great care seems to bave been taken to exclude all doubtful statements, and to show the cause of the occurrence of particular sets of plants, where this is possible. It is therefore thoroughly reliable, and from the scattered nature of the little that had previously been done, contains more new matter than is to be found in the first part.

The book is accompanied by sixteen plates of geological woodcuts, which are rough, and add but little to its value. There are also five plates of coloured sections, mostly founded on those of the Survey.

We must certainly congratulate the authors on the completion of their task, which has been carried out in a creditable manner, and has resulted in a useful and instructive book.

\section{OUR BOOK SHELF}

\section{Flowers. By J. E. Taylor. (Hardwicke and Bogue.)}

THIS is a compilation in small octavo, illustrated with many familiar woodcuts and coloured plates. A feature is the index of $\mathrm{I}, 000$ references. Very many of these, being only to the merest mention of names, might hare been omitted in favour of a glossary of terms, and more especially a list of works of reference.

The principal aim throughout the book is to convey that all the many adaptations of flowers to secure fertilisation are due to a Divine Creator, and not thought out by the plants themselves. The theory of Natural Select tion is bardly alluded to. 